\title{
Dampak Sosial Ekonomi Pengembangan Budidaya Rumput Laut Kultur Jaringan di Desa Agel, Kabupaten Situbondo
}

\author{
[Socio-Economic Impact in Development of Tissue Culture-Based \\ Seaweed Farming in Agel Village, Situbondo District]
}

\author{
Wiwien Mukti Andriyani, Ujang Komarudin A.K, Febriko S.
}

Balai Perikanan Budidaya Air Payau, Situbondo, Jawa Timur Jl. Raya Pecaron, Situbondo

\begin{abstract}
Abstrak
Kultur jaringan rumput laut menimbulkan harapan baik pembudidaya rumput laut terhadap kelangsungan usaha budidaya rumput laut di Desa Agel, Situbondo. Penelitian ini bertujuan untuk menganalisis dampak sosial ekonomi budaya terhadap budidaya rumput laut kultur jaringan dan Strategi pengembangan budidaya rumput laut kultur jaringan. Penelitian ini dilaksanakan di Desa Agel, Kecamatan Jangkar, Kabupaten Situbondo. Metode pengumpulan data untuk mengkaji dampak sosial ekonomi digunakan metode survei. Sampel diambil dengan simple random sampling. Analisis untuk mengkaji dampak sosial ekonomi budaya digunakan analisis regresi, dan untuk merumuskan strategi pengembangan budidaya rumput laut menggunakan analisis SWOT. Hasil penelitian terkait analisis sosial ekonomi pembudidaya rumput laut menunjukkan korelasi antara karakteristik sosial ekonomi budaya pembudidaya terhadap program budidaya rumput laut kultur jaringan. Secara ekonomi usaha budidaya rumput laut kultur jaringan lebih meningkatkan pendapatan pembudidaya dan ekonomi masyarakat sebesar $50-75 \%$, dan peningkatan pelaku usaha mencapai $85 \%$ dengan adanya peningkatan Laju pertumbuhan rumput laut kultur jaringan $1,4-9,3 \%$, dengan produksi 2-8 ton.siklus ${ }^{-1}$, serta peningkatan produktivitas $80 \%$. Sedangkan untuk strategi pengembangan budidaya adalah peningkatan strategi manajemen usaha budidaya rumput laut kultur jaringan dengan melihat kesesuaian lahan budidaya, peningkatan kualitas sumberdaya manusia, pemberdayaan kelembagaan usaha rumput laut, dan peningkatan sumber modal usaha budidaya rumput laut.
\end{abstract}

Kata kunci : rudidaya rumput laut kultur jaringan; dampak sosial ekonomi

\section{Abstract}

Seaweed tissue culture raises good hopes for seaweed farmers to the continuation of seaweed cultivation in Agel Village, Situbondo. This study aims to analyze the socio-economic and cultural impacts on tissue culture-based seaweed farming and their strategies of development. This research was conducted in Agel Village, Jangkar, Situbondo District. Data collection methods for assessing socio-economic impacts were used survey methods. Samples were taken by simple random sampling. The research method to assess the socio-economic impact was used a regression analysis method, and formulation of the strategies of development used SWOT analysis. The results of the study related to the socio-economic analysis of seaweed farmers showed a correlation between the socio-economic characteristics of the culture with farming development program of tissue culture-based seaweed. Economically, tissue culture seaweed could increases farmers' income and community economy by $50-75 \%$, and increasing of business actors to reached $85 \%$, by the increasing of growth rate of tissue culture-based seaweed 1,4$9,3 \%$, with production of $2-8$ tons.cycle ${ }^{-1}$, insted of $80 \%$ increase in productivity. While the management strategy to develop farming of tissue culture-based seaweed are improving the suitability of cultivated land, improving the quality of human resources, empowering institutional seaweed business, and increasing sources of capital for the seaweed cultivation business.

Keywords: socio-economic impact, tissue culture-based seaweed farming 


\section{Penulis Korespondensi}

Wiwien Mukti Andriyani | wiwinmukti@gmail.com

\section{PENDAHULUAN}

Rumput laut merupakan salah satu bahan pangan berasal dari laut yang sudah dikenal masyarakat bahkan sampai ke mancanegara. Masyarakat banyak yang membudidayakan rumput laut untuk memenuhi permintaan pasar yang semakin meningkat dan untuk menambah pendapatan. Rumput laut menjadi salah satu komoditas yang dijadikan sebagai mata pencaharian oleh masyarakat pesisir. Di Kabupaten Situbondo, rumput laut belum menjadi komoditas utama perikanan. Komoditas unggulan masih didominasi udang dan ikan kerapu. Namun demikian, pengembangan sentra budidaya rumput laut tumbuh pesat di wilayah tersebut. Dari aspek teknis, usaha budidaya rumput laut sangat mudah dilakukan, teknologinya sederhana, bibit banyak tersedia di alam dan waktu pemeliharaan relatif singkat. Sedangkan dari aspek ekonomi, usaha ini menguntungkan karena biaya operasionalnya murah, harga produk yang kompetitif dan pangsa pasar terbuka lebar.

Lahan budidaya rumput laut di Desa Agel, Kabupaten Situbondo merupakan lahan penanaman rumput laut yang selama ini menjadi sumber mata pencaharian sebagian warga setempat sejak tahun 2009. Lima tahun terakhir terjadi penurunan produksi dan mutu rumput laut. Hal tersebut dikarenakan adanya hama penyakit, pertumbuhan yang lambat, kegagalan panen, ditambah harga rumput laut yang rendah sehingga menimbulkan kekhawatiran bagi pembudidaya akan keberlanjutan usahanya. Namun dalam dua tahun ini usaha budidaya rumput laut kembali marak di Desa Agel. Program pengembangan budidaya rumput laut hasil kultur jaringan melalui bantuan bibit oleh BPBAP Situbondo mengubah paradigma pembudidaya dalam usaha budidaya rumput laut.

Penggunaan bibit rumput laut yang baik merupakan salah satu faktor utama pendukung keberhasilan usaha budidaya. Selama ini, bibit rumput laut didapatkan dari pengembangbiakan vegetatif rumput laut hasil panen. Penggunaan bibit vegetatif secara terus menerus tersebut dapat menurunkan keragaman genetik, laju pertumbuhan, kadar karaginan dan kekuatan gel serta meningkatkan kerentanan terhadap penyakit (Andriyani et al. 2018; Hurtado dan Cheney 2003). Untuk itu dilakukan upaya penyediaan bibit rumput laut yang unggul melalui teknik kutur jaringan. Manfaat penggunaan teknik tersebut antara lain untuk mendapatkan tanaman baru dalam jumlah banyak dalam waktu 
relatif singkat, yang mempunyai sifat fisiologis dan morfologis unggul sama dengan tanaman induknya.

Pemerintah RI melalui Peraturan Presiden nomor 33 tahun 2019 tentang Peta Panduan (Roadmap) Pengembangan Industri Rumput Laut Nasional Tahun 2018-2021, menunjukkan langkah serius dalam mengembangkan industri rumput laut. Pembangunan perikanan melalui budidaya rumput laut kultur jaringan memberikan harapkan pengembangan rumput laut wilayah pesisir potensial. Program pembangunan perikanan tersebut diyakini dapat memberikan perubahan di berbagai aspek kehidupan pembudidaya rumput laut, yaitu perubahan faktor sosial, ekonomi dan budaya. Oleh karena itu, budidaya rumput laut kultur jaringan diharapkan menjadi sarana untuk meningkatkan pendapatan masyarakat di wilayah pesisir, pulau-pulau kecil, pinggiran, dan juga perbatasan.

Akselarasi

pembangunan perikanan melalui pengembangan budidaya rumput laut kultur jaringan pasti akan memiliki dampak kehidupan sosial, ekonomi dan budaya bagi masyarakat. Pengembangan budidaya rumput laut kultur jaringan yang diterapkan pada individu masyarakat yang hidup dalam suatu lingkungan akan menyebabkan kehidupan sosial ekonomi budaya yang berbeda, seperti sistem interaksi, pola berfikir, lapangan kerja, pendapatan, dan lain-lain yang semuanya dapat berubah. Oleh sebab itu penelitian ini dilakukan untuk mengetahui dampak sosial ekonomi dan budaya dengan adanya program pengembangan budidaya rumput laut kultur jaringan serta strategi pengembangannya untuk memaksimalkan produktivitas perairan di wilayah Desa Agel, Kabupaten Situbondo.

\section{BAHAN DAN METODE}

\section{Lokasi dan Metode Pengumpulan data}

Penelitan ini dilaksanakan di Desa Agel, Kecamatan Jangkar, Kabupaten Situbondo. Penelitian dilakukan mulai dari Januari hingga Juli 2019. Metode pengumpulan data dengan metode survei, sedangkan sampel pertumbuhan rumput laut diambil menggunakan simple random sampling. Populasi penelitian adalah seluruh pembudidaya rumput laut sebanyak 17 orang, dan stakeholder di Desa Agel. Pengumpulan data dilakukan melalui (1) Observasi, yaitu pengamatan langsung terhadap berbagai kegiatan keadaan di lokasi penelitian, uji kimia, fisik, dan biologi di laboratorium, (2) Wawancara, yaitu mengumpulkan data dengan melakukan tanya jawab dengan pembudidaya untuk memperoleh informasi yang mendalam, dengan menggunakan alat bantu kuesioner, (3) 
Studi pustaka, yaitu mengumpulkan data dengan melakukan telaah pustaka melalui literatur dari berbagai sumber dan terkait dengan penelitian (Stake, 2009).

\section{Analisis Data}

Analisis data yang dilakukan menggunakan analisis statistik regresi yang didasarkan pada analisis karakteristik sosial ekonomi budaya masyarakat pembudidaya dan potensi budidaya rumput laut kultur jaringan dalam meningkatkan ekonomi dan pendapatan pembudidaya digunakan untuk melihat korelasi program pengembangan budidaya rumput laut kultur jaringan terhadap faktor ekonomi sosial budaya pembudidaya meliputi umur, pendidikan, jumlah anggota keluarga, lama tinggal, pengalaman budidaya, pendapatan dan pengeluaran pembudidaya rumput laut dan lain lain.

Untuk menjawab tujuan kedua digunakan analisis SWOT yaitu identifikasi berbagai faktor secara sistematis untuk merumuskan strategi organisasi/perusahaan. Analisis tersebut didasarkan pada logika yang dapat memaksimalkan kekuatan (Strength) dan peluang (Opportunities), namun secara bersamaan dapat meminimalkan kelemahan (Weakness) dan ancaman (Threats) (Salusu, 2015). Analisis SWOT salah satunya dapat dilakukan dengan menggunakan matrik SWOT. Model matriks mendahulukan faktor - faktor eksternal (ancaman dan peluang), kemudian melihat kapabilitas internal (kekuatan dan kelemahan). Suatu strategi dirumuskan setelah SWOT selesai dianalisis (Salusu, 2015). Matriks SWOT menghasilkan 4 strategi (Rangkuti, 2015), yaitu:

1. Strategi SO (Strategi kekuatanpeluang), menciptakan strategi yang menggunakan kekuatan untuk memanfaatkan peluang.

2. Strategi WO (Strategi kelemahanpeluang), menciptakan strategi yang meminimalkan kelemahan untuk memanfaatkan peluang yang ada.

3. Strategi ST (Strategi kekuatanancaman), menciptakan strategi dengan memanfaatkan kekuatan untuk menghindari atau memperkecil dampak dari ancaman eksternal.

4. Strategi WT (Strategi kelemahanancaman), didasarkan pada kegiatan yang bersifat defensif dan berusaha meminimalkan, serta menghindari ancaman.

\section{HASIL DAN PEMBAHASAN}

\section{Diskripsi Lokasi Budidaya dan Kependudukan}

Penelitian dilakukan di perairan Desa Agel, Kabupaten Situbondo yang memiliki letak geografis sebagai berikut : $7^{\circ} 42^{\prime} 54,5^{\prime \prime S}$ sd $7^{\circ} 42^{\prime} 53,7^{\prime \prime S}$ dan 
Tabel 1. Data kependudukan masyarakat Desa Agel, Kabupaten Situbondo

\begin{tabular}{cccccccc}
\hline $\begin{array}{c}\text { Struktur } \\
\text { Umur }\end{array}$ & $\begin{array}{c}\text { Laki- } \\
\text { Laki }\end{array}$ & Perempuan & $\begin{array}{c}\text { Jumlah } \\
\text { Total }\end{array}$ & KK & $\begin{array}{c}\text { Luas } \\
\text { (ha) }\end{array}$ & $\begin{array}{c}\text { Sex } \\
\text { Ratio }\end{array}$ & $\begin{array}{c}\text { Kepadatan } \\
\text { Jiwa/Ha }\end{array}$ \\
\hline $0-9$ & 237 & 230 & 467 & 1.995 & 585 & $93,76 \%$ & 7,7 \\
$10-19$ & 283 & 289 & 572 & & & & \\
$20-29$ & 280 & 297 & 577 & & & & \\
$30-39$ & 328 & 346 & 674 & & & & \\
$40-49$ & 367 & 359 & 726 & & & & \\
$50-59$ & 272 & 310 & 582 & & & & \\
$60-69$ & 257 & 270 & 527 & & & & \\
$>70$ & 140 & 207 & 347 & & & & \\
\hline Jumlah & $\mathbf{2 . 1 6 4}$ & $\mathbf{2 . 3 0 8}$ & $\mathbf{4 . 4 7 2}$ & & & & \\
\hline
\end{tabular}

Tabel 2. Tingkat pendidikan masyarakat Desa Agel, Kabupaten Situbondo

\begin{tabular}{llccrr}
\hline No & Pendidikan & Laki-laku & Perempuan & Jumlah & $\begin{array}{c}\text { Persentase } \\
(\%)\end{array}$ \\
\hline 1 & Tidak tamat SD & 142 & 123 & 265 & 5,612 \\
2 & Tamat SD & 714 & 833 & 1547 & 32,760 \\
3 & Tamat SLTP & 180 & 150 & 330 & 6,989 \\
4 & Tamat SLTA & 170 & 96 & 266 & 4,786 \\
5 & Tamat Akademi & 6 & 5 & 11 & 0,233 \\
6 & Sarjana & 20 & 9 & 29 & 0,614 \\
7 & Anak-anak <5 th & 991 & 1283 & 2274 & 48,160 \\
\hline & Jumlah & $\mathbf{2 2 2 3}$ & $\mathbf{2 4 9 9}$ & $\mathbf{4 7 2 2}$ & \\
\hline
\end{tabular}

$114^{\circ} 10^{\prime} 39,2^{\prime \prime} E$ sd $114^{\circ} 10^{\prime} 40,7^{\prime \prime} E$ yang membentang sepanjang pantai utara Desa Agel. Pantai Agel digunakan untuk aktifitas perikanan tangkap dan masih dalam tahap pengembangan pariwisata. Desa pesisir ini sangat dipengaruhi angin muson yaitu angin musim barat (Desember - Maret) dan angin musim timur (Juni - September) serta musim pancaroba di antara kedua muson tersebut. Pada musim barat angin dominan bertiup dari barat dengan kecepatan angin rata-rata 7,24 m.detik ${ }^{-1}$ atau pada kisaran 3,5-10 m.detik ${ }^{-1}$. Sedangkan saat musim timur angin bertiup dari arah timur laut dengan kecepatan 3,5-7,5 m.detik ${ }^{-1}$. Suhu udara rata-rata antara $22-32{ }^{\circ} \mathrm{C}$ dengan kelembaban udara 50 - 80\%. Pada musim penghujan, curah hujan di wilayah Agel berkisar 0 - $20 \mathrm{~mm}$ dengan persentase wilayah 100\%. Desa Agel 
Tabel 3. Data mata pencaharian masyarakat Desa Agel, Kabupaten Situbondo

\begin{tabular}{llrc}
\hline No & \multicolumn{1}{c}{ Mata Pencaharian } & Jumlah & Persentasi (\%) \\
\hline 1 & Pertanian & 1285 & 65,0 \\
2 & Nelayan/Perikanan & 237 & 12,0 \\
3 & Karyawan/buruh & 59 & 3,0 \\
4 & TNI/Polri/PNS & 4 & 0,2 \\
5 & Perdagangan & 297 & 15,0 \\
6 & Jasa Lainnya & 95 & 4,8 \\
\hline
\end{tabular}

termasuk dalam lingkup wilayah yang kering. Pasang surut permukaan air laut di wilayah Agel bersifat harian tunggal (diurnal tide), dalam satu hari terjadi satu kali air pasang dan satu kali air surut. Periode pasang surut rata-rata adalah 24 jam 50 menit. Level air tertinggi $1,75 \mathrm{~m}$ di atas duduk tengah dan terendah $0,5 \mathrm{~m}$ di bawah duduk tengah. Kecepatan maksimum arus permukaan laut pada musim barat maupun musim timur memiliki kisaran 10 - 21 m.detik $^{-1}$.

Keragaan sosial ekonomi budaya masyarakat Desa agel berdasar struktur umur dan jenis kelamin terbagi dalam 8 struktur yang ditampilkan pada Tabel 1. Selanjutnya, tingkat pendidikan masyarakat Desa Agel terbagi dalam 7 kategori dan ditampilkan pada Tabel 2. Mata pencaharian masyarakat di Desa Agel meliputi bidang pertanian, perikanan, industri, pemerintahan, jasa dan lainnya yang secara rinci dapat dilihat pada Tabel 3.

\section{Hasil}

Potensi Lahan Budidaya Rumput Laut

Hasil pengamatan kondisi perairan budidaya rumput laut dibandingkan dengan baku mutu air laut untuk budidaya perikanan sesuai SK Menteri Kependudukan dan Lingkungan Hidup Kep-02/MenKLH/1988; KepMen No. 51/MENKLH/2004 ditampilkan dalam Tabel 4.

\section{Karakteristik Sosial Ekonomi Budaya} Pembudidaya

Berdasarkan data keragaan kependudukan Desa Agel dihasilkan karakteristik sosial ekonomi budaya pembudidaya rumput laut yang terbagi dalam 8 variabel yaitu umur, tingkat pendidikan, lama tinggal, etnis, jumlah keluarga, pengalaman budidaya, pendapatan dan pengeluaran. Karakteristik tersebut disajikan pada Tabel 5 sebagai berikut: 
Tabel 4. Hasil analisis kualitas air lahan usaha budidaya rumput laut kultur jaringan di Desa Agel, Kabupaten Situbondo

\begin{tabular}{|c|c|c|c|c|}
\hline No & Parameter & Satuan & Hasil Analisis* & Baku Mutu \\
\hline 1 & $\begin{array}{l}\text { Fisika } \\
\text { Arus } \\
\text { Kecerahan } \\
\text { Suhu } \\
\text { Kedalaman } \\
\text { Substrat } \\
\text { Perlindungan }\end{array}$ & $\begin{array}{c}\text { m.detik }{ }^{-1} \\
- \\
{ }^{\circ} \mathrm{C} \\
\text { meter } \\
- \\
-\end{array}$ & $\begin{array}{c}10-21,2 \\
1,4-2 \\
28-31 \\
0,5-3 \\
\text { Pasir berlumpur } \\
\text { Terbuka } \\
\end{array}$ & $\begin{array}{c}20-40 \\
1-4,>5 \text { diinginkan } \\
24-31 \\
>2 \\
\text { Pasir } \\
\text { Terlindung }\end{array}$ \\
\hline 2 & $\begin{array}{l}\text { Kimia } \\
\text { pH } \\
\text { Salinitas } \\
\text { Nitrat } \\
\text { Phosphat } \\
\text { TAN } \\
\text { Amonia } \\
\text { Bahan Organik }\end{array}$ & $\begin{array}{l}\mathrm{ppm} \\
\mathrm{mg} \cdot \mathrm{L}^{-1} \\
\mathrm{mg} \cdot \mathrm{L}^{-1} \\
\mathrm{mg} \cdot \mathrm{L}^{-1} \\
\mathrm{mg} \cdot \mathrm{L}^{-1} \\
\mathrm{mg} \cdot \mathrm{L}^{-1}\end{array}$ & $\begin{array}{l}7,25-8,27 \\
29-34 \\
3,0-7,2 \\
<0,001 \\
0,071 \\
0,006 \\
60,2-64,46\end{array}$ & $\begin{array}{c}6,5-8,5 \\
28-33 \\
1-3 \\
0,021-0,1 \\
<0,02 \\
<80\end{array}$ \\
\hline 3 & $\begin{array}{l}\text { Biologi } \\
\text { Makro Algae } \\
\text { Identifikasi } \\
\text { plankton } \\
\text { Kepadatan } \\
\text { mikroalgae }\end{array}$ & $\begin{array}{c}- \\
\% \\
\text { sel.mL-1 }\end{array}$ & $\begin{array}{l}\text { Sedang } \\
99,99 \\
900-2.600\end{array}$ & $\begin{array}{c}\text { Ulva sp, Ceramium sp } \\
5-50 \% \\
\\
\text { Diatom, Jenis } \\
\text { Seletonema, } \\
\text { Chaetoceros, Thalasiotrik }\end{array}$ \\
\hline 4 & $\begin{array}{l}\text { Lingkungan } \\
\text { Pencemaran } \\
\text { Total bakteri } \\
\text { Presemtif Vibrio }\end{array}$ & $\begin{array}{l}- \\
\text { CFU.mL } \\
\text { CFU. }\end{array}$ & $\begin{array}{l}\text { Rendah } \\
8,0 \times 10^{4} \\
1,2 \times 10^{3}\end{array}$ & $<10^{4}$ \\
\hline
\end{tabular}

*Laboratorium Penguji BPBAP Situbondo

\section{Potensi Budidaya Rumput Laut Kultur Jaringan}

Potensi budidaya rumput laut $\mathrm{di}$

Desa Agel meliputi kawasan perairan pantai Agel yang mempunyai jarak sekitar $200 \mathrm{~m}$ dari tepi pantai sampai 500 $\mathrm{m}$ ke tengah laut dengan kedalaman air 0,5 - 5 meter. Perairan pantai Agel yang merupakan pantai landai sepanjang 3,7 $\mathrm{km}$ dengan luas 185 ha. Potensi tersebut belum termanfaatkan secara maksimal. Dari lahan yang ada, yang sudah dimanfaatkan seluas 15 ha atau sekitar $8.1 \%$.
Budidaya rumput laut di Desa Agel menggunakan metode pancang dasar. Bambu dengan panjang 8 meter digunakan sebagai pancang dasar. Dalam 1 unit budidaya, dibutuhkan 7 pasang bambu. Masing-masing tonggak bambu berjarak 1,5-2,5 m. Tali pangkal pengikat tali ris rumput laut menggunakan 3 bentang tali utama dengan total panjang 11 meter. Tali bentang utama dihubungkan dengan tonggak bambu menggunakan tali penghubung sepanjang $2-2,5 \mathrm{~m}$. Setiap 
Tabel 5. Karakteristik sosial ekonomi budaya pembudidaya rumput laut kultur jaringan di Desa Agel, Kabupaten Situbondo

\begin{tabular}{|c|c|c|c|c|c|}
\hline No & $\begin{array}{l}\text { Karakteristik } \\
\text { Pembudidaya }\end{array}$ & Kelas & Kriteria & $\begin{array}{l}\text { Jumlah } \\
\text { (orang) }\end{array}$ & $\begin{array}{c}\text { Persentase } \\
(\%)\end{array}$ \\
\hline \multirow[t]{3}{*}{1} & Umur & Rendah & $23-38$ & 7 & $41,18 \%$ \\
\hline & & Sedang & $39-53$ & 5 & 29,41 \\
\hline & & Tinggi & $53-67$ & 5 & 29,41 \\
\hline \multirow[t]{4}{*}{2} & Tingkat Pendidikan & Rendah & Tidak & 10 & 58,82 \\
\hline & & & sekolah & & \\
\hline & & Sedang & SD & 5 & 29,42 \\
\hline & & Tinggi & SLTP/SLTA & 2 & 11,76 \\
\hline \multirow[t]{3}{*}{3} & Lama Tinggal & Rendah & $17-33$ & 7 & 41,18 \\
\hline & & Sedang & $34-50$ & 8 & 47,06 \\
\hline & & Tinggi & $50-67$ & 2 & 11,76 \\
\hline \multirow[t]{3}{*}{4} & Jumlah Anggota & Rendah & $1-2$ & 8 & 47,06 \\
\hline & Keluarga & Sedang & $3-4$ & 8 & 47,06 \\
\hline & & Tinggi & $5-6$ & 1 & 5,88 \\
\hline \multirow[t]{2}{*}{5} & Etnis & Asli & & 15 & 88,23 \\
\hline & & Pendatang & & 2 & 11,77 \\
\hline \multirow[t]{3}{*}{6} & Pengalaman & Rendah & $5-8$ & 3 & 17,65 \\
\hline & & Sedang & $9-12$ & 12 & 70,59 \\
\hline & & Tinggi & $13-16$ & 2 & 11,76 \\
\hline \multirow[t]{3}{*}{7} & Pengeluaran & Rendang & $1-1,9 \mathrm{jt}$ & 8 & 47,06 \\
\hline & & Sedang & $2-2,9 \mathrm{jt}$ & 7 & 41,18 \\
\hline & & Tinggi & $3-3,9$ & 2 & 11,76 \\
\hline \multirow[t]{3}{*}{8} & Pendapatan & Rendah & $2-2,9 \mathrm{jt}$ & 7 & 41,18 \\
\hline & & Sedang & $3-3,9 \mathrm{jt}$ & 8 & 47,06 \\
\hline & & Tinggi & $>4 \mathrm{jt}$ & 2 & 11,76 \\
\hline
\end{tabular}

Tabel 6. Peningkatan laju pertumbuhan, produksi dan produktivitas rumput laut kultur jaringan di Desa Agel, Kabupaten Situbondo

\begin{tabular}{ccccccc}
\hline No & Tahun & $\begin{array}{c}\text { Jenis } \\
\text { Rumput } \\
\text { Laut }\end{array}$ & $\begin{array}{c}\text { Umur } \\
\text { Panen } \\
\text { (hari) }\end{array}$ & $\begin{array}{c}\text { Laju } \\
\text { Pertumbuhan } \\
\text { (\%) }\end{array}$ & $\begin{array}{c}\text { Produksi } \\
\text { (ton/siklus) }\end{array}$ & $\begin{array}{c}\text { Produktivitas } \\
\text { (\%) }\end{array}$ \\
\hline 1 & $<2017$ & Lokal & 45 & $0,8-0,9$ & $0,4-2$ & 80 \\
2 & 2017 & $\begin{array}{c}\text { Kultur } \\
\text { Jaringan } \\
3\end{array}$ & 30 & $1,4-3$ & $0,6-3$ & \\
\hline & 2019 & $\begin{array}{c}\text { Kultur } \\
\text { Jaringan }\end{array}$ & 25 & $5-9,3$ & $8-40$ & \\
\hline
\end{tabular}

tali penghubung pada unit pancang dasar diikatkan pada pancang bambu setinggi $1 \mathrm{~m}$. Tali utama diikatkan pada setiap pasang bambu secara simetris. Jarak antara tali utama dengan tali utama lainnya dalam satu pancang dasar adalah $24 \mathrm{~m}$. Kapasitas tali utama mampu menyangga 100 - 200 tali ris dengan panjang setiap tali ris adalah 24 $\mathrm{m}$. Masing-masing tali ris terdapat 320 titik (double) pengikat rumput laut. Bibit rumput laut sebanyak 25 - 35 gram 
diikatkan sepanjang tali dengan jarak antar titik lebih kurang $10 \mathrm{~cm}$.

Hasil pengujian program budidaya dengan faktor ekososbud pembudidaya

Untuk mengetahui hubungan antara potensi budidaya rumput laut kultur jaringan dengan dampak ekonomi sosial budaya di Desa Agel, dilakukan analisis regresi linear berganda dengan hasil regresi nilai t pendidikan $(-1,202)$, lama tinggal $(-2,427)$, jumlah anggota keluarga $(-2,033)$, sedangkan Umur $(3,527)$, etnis $(0,269)$; pengalaman $(2,711)$ dan pengeluaran $(11,492)$, sehingga didapatkan hubungan antara peningkatan ekonomi dan pendapatan terhadap variabel faktor sosial, ekonomi dan budaya responden.

\section{Analisis SWOT}

Pembobotan unsur-unsur dalam analisis SWOT berdasarkan potensi lahan budidaya rumput laut, karakteristik sosial ekonomi budaya pembudidaya, dan potensi budidaya rumput laut kultur jaringan. Selanjutnya diperoleh faktor kekuatan yang dimiliki adalah (1) minat masyarakat tinggi dalam usaha budidaya, (2) tenaga kerja mudah didapat, (3) metode budidaya sederhana dan murah, (4) potensi lahan budidaya yang luas, (5) kualitas dan kuantitas bibit rumput laut kultur jaringan tercukupi.

Tabel 7. Peningkatan Jumlah pelaku usaha, pendapatan dan ekonomi pembudidaya rumput laut kultur jaringan di Desa Agel, Kabupaten Situbondo

\begin{tabular}{ccclcccc}
\hline No & Tahun & $\begin{array}{c}\text { Jumlah } \\
\text { Pelaku }\end{array}$ & Perubahan (\%) & $\begin{array}{c}\text { Rerata } \\
\text { Produksi } \\
\text { kg/org/siklus }\end{array}$ & $\begin{array}{c}\text { Rerata } \\
\text { Pendapatan }\end{array}$ & Harga/kg & $\begin{array}{c}\text { Peningkatan } \\
\text { Ekonomi }\end{array}$ \\
\hline 1 & $<2017$ & 12 & - & 500 & $1,5 \mathrm{jt}$ & 2500 & - \\
2 & 2017 & 3 & Menurun $75 \%$ & 750 & $4,0 \mathrm{jt}$ & 4000 & $50 \%$ \\
3 & 2019 & 17 & Meningkat $85-88 \%$ & 3000 & $12,0 \mathrm{jt}$ & 4000 & $75 \%$ \\
\hline
\end{tabular}

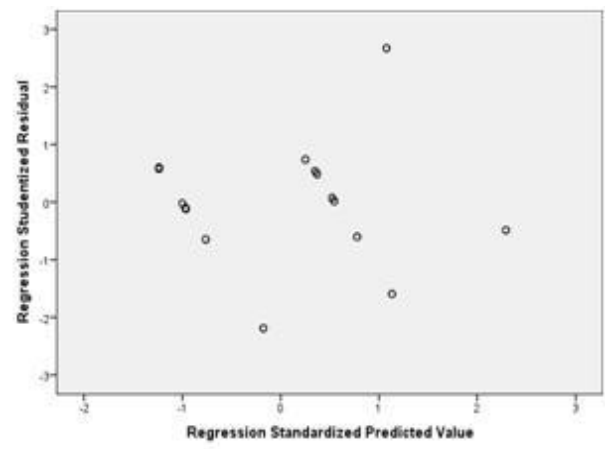

Gambar 1. Analisis regresi linier berganda faktor peningkatan ekonomi dan pendapatan terhadap faktor sosial ekonomi budaya pembudidaya rumput laut kultur jaringan di Desa Agel, Kabupaten Situbondo 
Tabel 8. Hasil komponen SWOT strategi pengembangan usaha budidaya rumput laut kultur jaringan di Desa Agel, Kabupaten Situbondo

\begin{tabular}{lcc}
\hline \multicolumn{1}{c}{ Komponen SWOT } & Bobot & Prioritas Relatif \\
\hline Kekuatan/Strength $(\mathrm{S})$ & 0,6 & $\mathrm{P} 2$ \\
Kelemahan/Weakness $(\mathrm{W})$ & 0,4 & $\mathrm{P} 3$ \\
Peluang/Opportunities (O) & 0,8 & $\mathrm{P} 1$ \\
Ancaman/Threats $(\mathrm{T})$ & 0,2 & $\mathrm{P} 4$ \\
\hline
\end{tabular}

Faktor kelemahan meliputi (1) kurangnya pengetahuan dalam usaha budidaya rumput laut, (2) kurangnya modal usaha, (3) kurangnya industri rumah tangga untuk hasil olahan rumput laut, (4) kemitraan usaha yang masih rendah, (5) serangan hama dan penyakit. Faktor peluang meliputi (1) potensi pasar besar, (2) program unggulan pemerintah, (3) kualitas perairan masih layak untuk budidaya rumput laut (4) usaha budidaya sangat menguntungkan, (5) perairan pantai belum termanfaatkan secara optimal. Faktor ancaman berupa (1) perubahan iklim global, (2) konflik pemanfaatan lahan budidaya, (3) harga rumput laut yang fluktuatif, (4) belum adanya tata ruang, (5) masih kurangnya bimbingan dan penyuluhan dari instansi terkait.

\section{Pembahasan}

\section{Potensi Lahan Dan Budidaya Rumput} Laut Kultur Jaringan

Secara umum hasil analisis kondisi lingkungan perairan dan kualitas air lahan budidaya rumput laut di Desa Agel masih dalam kisaran baku mutu air laut untuk budidaya perikanan sesuai SK Menteri KLH Kep-02/MenKLH/1988; KepMen No. 51/MENKLH/2004. Namun, areal budidaya rumput laut di Desa Agel memiliki keterlindungan yang kurang baik. Menurut Mudeng, Kolopita, dan Rahman (2015), Keterlindungan merupakan salah satu faktor resiko yang dinilai penting dalam budidaya rumput laut, karena akan berdampak pada kerusakan sarana budidaya dan tumbuhan rumput laut. Keterlindungan mengurangi pengaruh angin dan gelombang yang besar serta memudahkan dalam memasang konstruksi sarana budidaya dan pengontrolan. Kondisi lingkungan perairan Desa Agel masih dalam katagori layak untuk budidaya rumput laut. Berdasarkan penelitian Wibianto (2016) pola arus pesisir utara Jawa Timur pada musim barat berasal dari barat daya. Angin mempengaruhi arah dan kecepatan arus pesisir utara yang menyebabkan penyimpangan arah arus 
sebesar $48,79^{\circ}$, sehingga arah dan kecepatan angin membentuk kecepatan arus dengan kisaran 2,94\%. BMKG (2019) menyatakan bahwa tinggi gelombang laut wilayah Kabupaten Situbondo pada musim barat mencapai 0,5-1,75 m dan pada musim timur berada pada kisaran 0,5 0,75 m. Dapat diartikan bahwa angin dan gelombang di wilayah Desa Agel masih dalam batasan normal dan cenderung rendah.

Menurut Arisandi dan Farid (2014), kedalaman perairan yang baik untuk budidaya rumput laut $E$. cottonii adalah $30-60 \mathrm{~cm}$ pada waktu surut terendah untuk (lokasi yang berarus kencang) metoda lepas dasar. Kondisi ini untuk menghindari rumput laut mengalami kekeringan dan mengoptimalkan perolehan sinar matahari. Tantangan yang dihadapi pembudidaya adalah lahan bertopografi pantai yang landai dengan kedalaman 0,5 - $3 \mathrm{~m}$, dan substrat pasir berlumpur yang mengindikasikan gerakan air kurang. Kondisi tersebut menyebabkan thalus rumput laut mudah ditempeli organisme fouling dan lumpur. Penempelan pada thalus rumput laut dapat menghambat pertumbuhan rumput laut, menghambat penyerapan zat hara, menghalangi sinar matahari yang dibutuhkan dalam proses fotosintesis, terjadinya kompetisi makanan (nutrien), dan kompetisi ruang. Hal ini sesuai dengan pernyataan Muñoz dan Fotedar (2010) bahwa epifit menghambat tingkat pertumbuhan inangnya dan akibatnya dapat menurunkan biomassa baik secara langsung maupun secara tidak langsung, melalui kompetisi dengan alga inangnya yaitu mengurangi oksigen, karbon dioksida, nutrient dari perairan, meningkatkan beban, menyebabkan kerusakan, mengurangi fotosintesis, dan dapat menembus jaringan inang. Namun Mudeng et al. (2015) mempunyai pendapat berbeda, arus dengan kecepatan $>50 \quad \mathrm{~cm}^{-\operatorname{detik}^{-1}}$ dapat menyebabkan kekeruhan dan menghalangi penetrasi cahaya matahari, sehingga kotoran dapat menutupi permukaan thalus, yang akan mengganggu pertumbuhan dan perkembangan rumput laut. Silt atau endapan lumpur berupa kotoran yang terbawa oleh arus yang menempel lama di permukaan thalus dapat menyebabkan pembusukan hingga membuat rumput laut mati. Silt yang menempel pada permukaan thalus dapat dilepas dengan melakukan pengontrolan berkala dan mengoyang-goyangkan tali ris.

Perkembangan rumput laut kultur jaringan di Perairan Agel, Situbondo menunjukkan pertumbuhan yang meningkat setiap bulannya. Namun, kegiatan budidaya pada musim-musim tertentu cenderung mengalami 

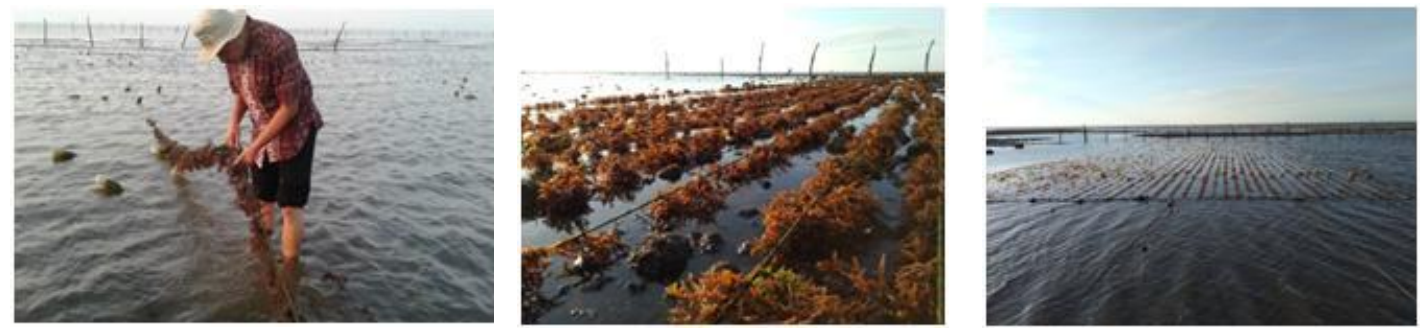

Gambar 2. Budidaya rumput laut K. Alvarezii di pesisir Desa Agel, -Situbondo

penurunan kualitas budidaya yang ditandai dengan jumlah bobot mutlak yang tidak mengalami peningkatan bahkan hasil panen yang berkurang. Hal ini disebabkan oleh penurunan kualitas air serta adanya organisme penganggu yang menempel pada rumput laut. Hama rumput laut antara lain larva bulu babi (Tripneustes sp) yang bersifat planktonik dan menempel pada thallus, larva kekerangan (Trochophore) yang awalnya menempel dan setelah dewasa memakan rumput laut dan ikan baronang (Siganus sp). Menurut Parenrengi, Rachmansyah, dan Suryati (2010) solusi untuk menghindari ancaman organisme penganggu seperti ikan baronang adalah melalui pola penanaman serentak. Metode budidaya rumput laut di Pesisir Agel ditunjukkan pada Gambar 2.

Produksi budidaya rumput laut kultur jaringan mencapai rasio 1:4-5 atau meningkat $4-5$ kali lipat dari berat awal, dengan laju pertumbuhan maksimal sebesar $9,31 \%$. hari ${ }^{-1}$. Laju pertumbuhan tersebut sesuai dengan pendapat Atmadja yang disampaikan oleh Abdullah (2011) bahwa budidaya rumput laut yang baik memiliki laju pertumbuhan rumput laut minimal 3\% setiap harinya. Neksidin, Pangerang, dan Emiyarti (2013) mengutip pernyataan Parenrengi dan Sulaeman menyatakan bahwa perlu aspek biologi yang perlu diketahui untuk meningkatkan pertumbuhan rumput laut yaitu ukuran bibit rumput laut yang ditanam. Penggunaan bibit thallus yang berasal dari bagian ujung dapat memberikan laju pertumbuhan lebih tinggi dibandingkan dengan bibit thallus yang berasal dari bagian pangkal. Percabangan ke berbagai arah dengan batang-batang utama keluar saling berdekatan di daerah basal serta bersifat berseling (alternatus), tidak teratur, serta dapat bersifat percabangan dua atau percabangan tiga-tiga. Ditambahkan oleh KKP (2014) bahwa salah satu faktor yang mempengaruhi keberhasilan budidaya rumput laut adalah pemilihan bibit. Dengan menggunakan bibit yang berkualitas baik dapat meningkatkan produksi rumput laut. Rumput laut yang dihasilkan melalui teknik kultur jaringan mempunyai kelebihan dan keunggulan mampu dibudidayakan di perairan yang 

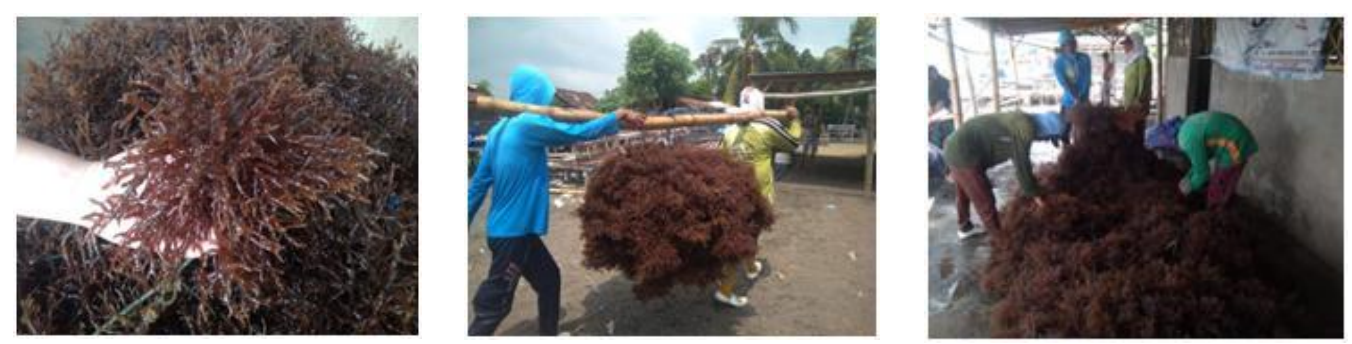

Gambar 3. Pemanenan rumput laut dengan mengangkat seluruh tanaman

keruh, mampu tetap hidup pada salinitas rendah, dan tahan terhadap curah hujan tinggi.

Dalam proses budidaya, pemanenan rumput laut dilakukan secara periodik untuk perbanyakan bibit atau penjualan. Pemanenan dilakukan pada umur 25 - 30 hari. Pemanenan rumput laut dilakukan dengan mengangkat seluruh tanaman. Cara ini memerlukan waktu kerja yang lebih singkat, karena pelepasan tanaman dari tali dilakukan di darat. Kelebihan cara ini adalah pada saat panen dapat dilakukan seleksi untuk penanaman kembali dari bibit-bibit rumput laut yang masih muda dengan laju pertumbuhan tinggi. Pemanenan rumput laut di Pesisir Agel ditunjukkan pada Gambar 3. Rumput laut yang dihasilkan pembudidaya dijual dalam kondisi basah maupun kering. Dalam kondisi basah, rumput laut dihargai hinggaRp. $4.000 \mathrm{~kg}^{-1}$. Umumnya pembelian dalam bentuk basah diperuntukkan untuk bibit vegetatif. Sedangkan harga rumput laut kering mencapai Rp. 18.000 - $20.000 \mathrm{~kg}^{-1}$. Rumput laut kering dijual ke pengumpul di kota Surabaya, Banyuwangi, dan Probolinggo.

\section{Karakteristik Sosial Ekonomi Budaya} Pembudidaya

Keragaan sosial ekonomi budaya masyarakat Desa Agel berdasar data jumlah penduduk adalah 4.472 jiwa (1.995 KK) dengan kepadatan 7,7 jiwa.ha-1. Jika dibandingkan data sebelumnya sebesar 4.772 jiwa, artinya terjadi penurunan sebesar 6,3\% (300 jiwa). Jumlah penduduk wilayah tersebut memiliki tren menurun dibanding tahun sebelumnya, akibat ditemukannya data ganda, perpindahan domisili, meninggal dan buruh musiman. Jumlah penduduk laki-laki Desa Agel lebih sedikit dibandingkan perempuan dengan sex ratio sebesar $93,76 \%$. Sex ratio adalah perbandingan antara banyaknya jumlah penduduk laki-laki dengan banyaknya jumlah penduduk perempuan pada suatu daerah dalam waktu tertentu. Penduduk Desa Agel berdasarkan umur terbagi dalam 8 kelompok umur dan didominasi kelompok umur 40 -49 tahun, diikuti kelompok umur 30 - 39 tahun. Artinya sebagian besar penduduk Desa Agel 
merupakan kelompok berusia produktif. Tingkat pendidikan sebagian besar penduduk Desa Agel yaitu SD (32,76\%), diikuti tamatan sekolah SLTP/SLTA $(11,77 \%)$ yang artinya telah banyak penduduk Desa Agel yang mengenyam pendidikan formal. Dari Tabel 3 . diketahui bahwa sebagian besar penduduk Desa Agel berprofesi sebagai petani (65\%), sedangkan yang berprofesi di bidang perikanan sebanyak $12 \%$, dan yang spesifik sebagai pembudidaya rumput laut sebanyak 17 orang (40,3\%).

Kelembagaan yang terlibat dalam usaha rumput laut di Desa Agel.Kabupaten Situbondo meliputi :

1. KKP, Balai Perikanan Budidaya Air Payau (BPBAP)

KKP secara langsung terlibat dalam usaha budidaya melalui Unit Pelaksana Teknis (UPT) BPBAP yang sangat terkait dengan pengembangan budidaya rumput laut kultur jaringan dalam hal penyediaan bibit sebar rumput laut kultur jaringan.

2. Dinas Kelautan dan Perikanan Kabupaten

Dinas secara langsung melakukan pembinaan terhadap masyarakat Desa Agel dalam usaha budidaya rumput laut.

3. Perguruan Tinggi

Perguruan tinggi yang aktif terlibat dalam usaha rumput laut adalah
Universitas Airlangga, UII Sukorejo, STA Nurul Huda, Universitas Jember, Universitas Muhamadiyah Jember dll dalam bentuk praktek kerja lapang, KKN dan magang bagi mahasiswa serta penelitian oleh lembaga terkait.

4. Lembaga Perbankan

Lembaga terlibat penyediaan modal kerja antara lain BRI.

5. Kelompok Tani Rumput laut Merupakan wadah pembudidaya rumput laut dalam pengembangan program yang tengah berlangsung.

6. Pengepul

Berperan dalam pemasaran hasil produksi rumput laut sehingga usaha budidaya dapat bergulir.

7. Investor

Berperan dalam permodalan, kerjasama usaha budidaya rumput laut.

Hubungan program budidaya dengan karakteristik ekososbud pembudidaya

Hasil analisis karakteristik sosial ekonomi budaya pembudidaya rumput laut menunjukkan adanya hubungan antara peningkatan ekonomi dan pendapatan pembudidaya rumput laut kultur jaringan. Variabel umur, etnis, pengalaman dan pengeluaran berpengaruh positif terhadap peningkatan ekonomi dan pendapatan pembudidaya. Pembudidaya memiliki kematangan umur, etnis asli Desa Agel 
dan mempunyai pengalaman lebih banyak dalam budidaya rumput laut, maka memiliki perhatian lebih dan kearifan lokal terhadap lingkungan dan keberlangsungan program budidaya rumput laut. Semakin tinggi variabelvariabel tersebut maka semakin besar pengaruhnya terhadap peningkatan produksi rumput laut kultur jaringan yang dihasilkan dan berimbas langsung terhadap peningkatan ekonomi dan pendapatan pembudidaya.

Pendidikan, lama tinggal di Desa Agel, jumlah anggota keluarga berpengaruh negatif terhadap peningkatan ekonomi dan pendapatan pembudidaya. Pada umumnya pembudidaya rumput laut di Desa Agel memiliki tingkat pendidikan rendah. Program budidaya rumput laut kultur jaringan telah mampu mengubah pola pikir masyarakat Desa Agel yang berpendidikan rendah bahwa mereka bisa mengembangkan rumput laut kultur jaringan. Budidaya rumput laut di Desa Agel tidak hanya dikembangkan oleh penduduk asli setempat, namun juga menarik minat para pendatang/investor sebagai pelaku usaha budidaya rumput laut kultur jaringan di Desa Agel. Program pengembangan budidaya rumput laut terhadap sasaran sebagai upaya pemberdayaan masyarakat tanpa melihat spesifikasi pendidikan mampu meningkatkan minat usaha masyarakat.
Berdasarkan hasil analisis regresi linear berganda (Gambar 1) diperoleh bahwa nilai signifikansi adalah 0 , kurang dari 0,05 , maka secara simultan faktor sosial, ekonomi dan budaya berpengaruh signifikan terhadap peningkatan ekonomi dan pendapatan responden. Nilai $R$ Square sebesar 0,869, artinya $87 \%$ faktor-faktor yang mempengaruhi peningkatan ekonomi responden dapat dijelaskan oleh variabel penelitian (pengeluaran, pendapatan, jumlah anggota keluarga, lama tinggal, pengalaman, pendidikan, etnis, umur), sisanya sebanyak $13 \%$ dijelaskan oleh variabel lain yang tidak diteliti.

Penelitian ini menunjukkan bahwa sosial ekonomi budaya pembudidaya berpengaruh dan dipengaruhi peningkatan ekonomi/pendapatan pembudidaya rumput laut. Peningkatan ekonomi dan pendapatan pembudidaya rumput laut berpengaruh positif terhadap progres pengembangan budidaya rumput laut kultur jaringan.

\section{Analisis Strategi Pengembangan} Budidaya Rumput laut

Perubahan lingkungan budidaya menjadi salah satu penyebab pembudidaya rumput laut rentan akan ketidakpastian ekonomi yang terjadi. Ketidakpastian ekonomi terjadi karena perubahan kondisi lingkungan yang menyebabkan tingkat kesejahteraan menurun. Hal ini sesuai dengan 
pendapat Onuoha (2008), yang menyatakan kesulitan hidup masyarakat pesisir disebabkan oleh hubungan antara nelayan dan lingkungannya terutama pesisir dan laut yang juga diliputi oleh situasi yang tidak pasti dan perubahan yang terjadi. Sedangkan menurut Titi dan Singh (2002), perubahan yang terjadi akibat adanya tekanan perubahan kondisi lingkungan yang tinggi, dapat menyebabkan kesejahteraan nelayan akan semakin merosot sehingga perlu adanya antisipasi dengan melakukan strategi-strategi alternatif untuk meminimalisir hal tersebut.

Tabel 8 menunjukkan bahwa faktor peluang menempati prioritas pertama dengan bobot 0,8 , selanjutnya disusul oleh faktor kekuatan dengan nilai bobot 0,6 . Faktor kelemahan menempati urutan ketiga dengan bobot 0,4 dan faktor ancaman dengan bobot 0,2 menempati urutan terakhir. Faktor yang berperan dalam strategi pengembangan usaha budidaya rumput laut kultur jaringan berdasar prioritas masing-masing faktor pendukung meliputi:

1. Prioritas Pada Faktor Kekuatan Berdasarkan hasil analisis, faktor kekuatan dalam strategi pengembangan usaha budidaya rumput laut kultur jaringan yaitu minat masyarakat dalam usaha budidaya rumput laut dan Metode budidaya sederhana dan murah menempati urutan pertama (bobot $0,6)$, selanjutnya faktor kekuatan tenaga kerja mudah didapat dan kualitas dan kuantitas bibit rumput laut kultur jaringan tercukupi (bobot $0,4)$ dan prioritas terakhir adalah potensi lahan budidaya yang luas untuk pengembangan usaha budidaya rumput laut (bobot 0,1 ).

2. Prioritas Pada Faktor Kelemahan Hasil analisis faktor kelemahan yang utama adalah kurangnya pengetahuan dalam usaha budidaya rumput laut (bobot 0,4), kemudian disusul dengan kurangnya modal usaha dan Kemitraan usaha yang masih rendah (bobot 0,1). Rentan terhadap serangan hama dan penyakit dan kurangnya industri rumah tangga untuk hasil olahan rumput laut (bobot 0,025 ).

3. Prioritas Pada Faktor Peluang Faktor peluang yang menjadi prioritas adalah potensi pasar komoditas rumput laut yang besar (bobot 0,8), kemudian kualitas perairan masih layak untuk budidaya rumput laut, usaha budidaya sangat menguntungkan, dan perairan pantai belum termanfaatkan secara optimal. (bobot 0,3), dan yang menjadi prioritas terakhir adalah program unggulan pemerintah (bobot 0,2).

4. Prioritas Pada Faktor Ancaman 
Hasil analisis dari faktor ancaman meliputi harga rumput laut yang fluktuatif (bobot 0,2), selanjutnya perubahan iklim global yang dapat mempengaruhi produksi secara signifikan (bobot 0,15), kemudian faktor ancaman masih kurangnya bimbingan dan penyuluhan dari instansi terkait (bobot 0,1), disusul konflik pemanfaatan lahan budidaya (bobot 0,075 ) dan terakhir ancaman belum adanya tata ruang (bobot 0,05).

Berdasarkan hasil identifikasi faktor internal dan eksternal untuk analisis SWOT maka diperoleh bobot faktor internal 2,750 nilanya lebih besar dari faktor eksternal 2,475. Sehingga strategi yang dilakukan untuk pengembangan usaha budidaya rumput laut kultur jaringan adalah ST (StrengthsThreats), yakni memanfaatkan kekuatan yang ada untuk menghadapi ancaman. Dari analisis tersebut diperoleh 4 arahan strategi pengembangan budidaya rumput laut kultur jaringan yaitu :

1. Kesesuaian lahan budidaya Potensi lahan budidaya di Desa Agel yang luas perlu dioptimalkan untuk pengembangan usaha budidaya rumput laut. Pemanfaatan pantainya perlu diatur oleh pemerintah setempat melalui instansi terkait, agar pemanfaatan lokasi budidaya sesuai peruntukan. Untuk menghindari terjadinya pemanfaatan lahan oleh masyarakat secara tidak terkendali perlu disusun tata ruang kegiatan budidaya laut. Tingginya minat masyarakat melakukan usaha budidaya rumput laut dapat mengakibatkan eksploitasi lahan tanpa mempertimbangkan dampak negatif terhadap lingkungan. Di samping itu, Pemanfaatan lahan budidaya yang bersinggungan dengan stakeholder lainnya untuk pariwisata pantai dan perikanan tangkap berpotensi menimbulkan konflik. Dibutuhkan penataan lokasi usaha budidaya rumput laut agar dapat memudahkan pembudidaya dalam memanfaatkan pesisir Desa Agel secara optimal. Penataan lokasi usaha budidaya rumput laut penting dilakukan karena fluktuasi kualitas air lahan budidaya rumput laut akibat adanya perubahan iklim global. Perubahan iklim secara langsung dapat mempengaruhi kualitas perairan. Terganggunya kualitas air budidaya akan menyebabkan organisme rumput laut terganggu. Oleh karena itu, penataan lokasi perlu disesuaikan dengan daya dukung, sehingga pembudidaya dapat mengetahui titik lokasi yang layak untuk usaha budidaya rumput laut. 
2. Peningkatan kualitas sumberdaya manusia,

Pembudidaya rumput laut di Desa Agel sebagian besar tidak sekolah atau tidak tamat SD (58,82\%), sehingga memiliki pola pikir tradisional, interaksinya terbatas dan model budidaya yang diterapkan sederhana sesuai teknologi yang diterapkan pendahulunya. Peningkatan kualitas sumberdaya manusia dapat dilakukan melalui program bimbingan dan penyuluhan oleh instansi terkait terhadap teknik budidaya rumput laut kultur jaringan, sehingga dapat mengembangkan wawasan dan pengetahuan pembudidaya serta kandidat pembudidaya rumput laut lainnya. Dengan transfer pengetahuan usaha budidaya rumput laut kultur jaringan yang memadai, pembudidaya akan mampu meningkatkan produksi, mencegah serangan hama penyakit rumput laut secara dini serta menjaga kualitas perairan agar memiliki daya dukung optimal untuk pertumbuhan rumput laut. Program bimbingan dan penyuluhan usaha budidaya rumput laut dapat menumbuhkan minat wirausaha pembudidaya, keluarga dan masyarakat sekitarnya untuk membentuk industri rumah tangga hasil olahan rumput laut.
Diversifikasi usaha yang tumbuh dari program pengembangan budidaya rumput laut dapat meningkatkan minat masyarakat Desa Agel lainnya untuk menekuni usaha budidaya rumput laut.

3. Pemberdayaan kelembagaan usaha rumput laut,

Peningkatan kapasitas kelembagaan usaha budidaya rumput laut sangat diperlukan pada proses produksi mulai dari hulu sampai hilir. Penggunaan bibit yang baik dapat mendukung keberhasilan usaha budidaya rumput laut. Kualitas dan kuantitas bibit rumput laut yang baik diperoleh dari hasil teknik kultur jaringan rumput laut. Keunggulan bibit rumput laut kultur jaringan adalah ketersediaan benih yang berkelanjutan, memiliki kualitas yang baik, mampu dibudidayakan di perairan yang keruh, mampu tetap hidup pada salinitas rendah serta tahan terhadap curah hujan tinggi. Pengembangan budidaya rumput laut kultur jaringan sudah dilakukan melalui jalinan kerjasama antara kelompok pembudidaya dengan BPBAP Situbondo. Kebutuhan rumput laut kultur jaringan diprediksi akan terus meningkat di masa depan. Pangsa pasar rumput laut terbuka lebar, karena rumput laut secara luas dibutuhkan dalam 
bidang industri makanan, farmasi, kesehatan, kosmestik dan lain-lain. Perbaikan sistem pemasaran rumput laut perlu dilakukan, karena selama ini pembudidaya memasarkan produknya ke pengumpul, sehingga harga rumput laut tergantung dari pengumpul. Pemberdayaan kelompok tani, koperasi perikanan, investor dan perguruan tinggi serta lembaga terkait perlu ditingkatkan untuk kesejahteraan pembudidaya rumput laut. Pengembangan budidaya rumput laut merupakan program unggulan pemerintah, keseriusan pemerintah dalam mengembangkan industri rumput laut tertuang dalam Peraturan Presiden nomor 33 tahun 2019. Pembangunan perikanan melalui budidaya rumput laut kultur jaringan dapat memberikan perubahan di berbagai aspek kehidupan sosial ekonomi budaya pembudidaya. Pemerintah perlu menetapkan regulasi harga komoditas rumput laut, agar harga rumput laut tidak fluktuatif. Dengan demikian, program pengembangan usaha budidaya rumput laut kultur jaringan memberikan kepastian ekonomi yang menyebabkan tingkat kesejahteraan, taraf hidup dan pendapatan masyarakat pesisir meningkat.
4. Peningkatan modal usaha budidaya Usaha budidaya rumput laut sangat menguntungkan, dikarenakan rumput laut sangat mudah untuk dibudidayakan, teknologi budidayanya telah dikuasai dan mudah untuk diaplikasikan, serta biaya produksi yang relatif murah dan terjangkau. Kurangnya modal usaha seringkali menjadi kendala pembudidaya untuk mengembangkan usaha budidayanya dan faktor tersebut dapat pula menyurutkan minat masyarakat dalam menekuni usaha ini. Strategi peningkatan sumber modal usaha budidaya rumput laut dapat diusahakan melalui perbankan dengan bunga rendah, Lembaga Pengelola Modal Usaha Kelautan dan Perikanan (LPMUKP), kredit Usaha Mikro dan Kecil (UMK), Kredit Usaha Rakyat (KUR), dan lain-lain. Permen KP 18/2016 tentang Jaminan Perlindungan atas Risiko kepada Nelayan, Pembudidaya Ikan dan Petambak Garam mengamanatkan perlindungan terkait resiko usaha yang dialami oleh pembudidaya ikan kecil akibat serangan wabah penyakit dan/atau bencana alam yang diwujudkan dalam program Asuransi Perikanan bagi Pembudidaya Ikan Kecil. 


\section{SIMPULAN DAN SARAN}

Hasil analisis regresi linear berganda menunjukkan secara simultan peningkatan ekonomi dari adanya pengembangan budidaya rumput laut kultur jaringan berpengaruh signifikan terhadap faktor sosial, ekonomi dan budaya pembudidaya.

Strategi pengembangannya untuk memaksimalkan produktivitas perairan meliputi kesesuaian lahan budidaya, peningkatan kualitas sumberdaya manusia, pemberdayaan kelembagaan usaha rumput laut, dan peningkatan sumber modal usaha budidaya rumput laut.

Perlu kajian pada kondisi lahan budidaya rumput laut Desa Agel yang terbuka menggunakan teknik budidaya rumput laut metode rakit atau long line.

\section{DAFTAR PUSTAKA}

Abdullah, Annur Ahadi. 2011. "Teknik Budidaya Rumput Laut (Kappaphycus alvarezii) dengan Metode Rakit Apung di Desa Tanjung, Kecamatan Saronggi, Kabupaten Sumenep, Jawa Timur [Technique Culture of Sea Weed (Kappaphycus alvarezii) with Flouting Raft Method in Tanjung Village, Sa." Jurnal IImiah Perikanan dan Kelautan 3(1):2126.
Andriyani, Wiwien Mukti, Komsatun, Prilastini, dan Wismo W. 2018. "Optimasi Hormon Pertumbuhan Pada Produksi Kalus Rumput Laut Kultur Jaringan." Jurnal Perekayasaan Budidaya Payau dan Laut 1:79-86.

Arisandi, Apri dan Akhmad Farid. 2014 "Dampak faktor ekologis terhadap sebaran penyakit ice-ice." Jurnal Kelautan: Indonesian Journal of Marine Science and Technology $7(1): 20-25$

BMKG. 2019. "Prakiraan Cuaca Jawa Timur." Diambil 15 Agustus 2019 (https://www.bmkg.go.id/cuaca/pra kiraan-cuaca-

indonesia.bmkg?Prov=12\&NamaP rov=Jawa Timur).

Hurtado, Anicia Q. dan Donald P. Cheney. 2003. "Propagule production of Eucheuma denticulatum (Burman) Collins et Harvey by tissue culture." Botanica Marina 46(4):338-41.

KKP. 2014. "Perikanan Budidaya Indonesia."

Mudeng, Joppy D., Magdalena E. .. Kolopita, dan Abdul Rahman. 2015. "Kondisi Lingkungan Perairan Pada Lahan Budidaya Rumput Laut Kappaphycus alvarezii Di Desa Jayakarsa Kabupaten Minahasa Utara." e- 
Journal BUDIDAYA PERAIRAN 3(1):172-86.

Muñoz, Julieta dan Ravi Fotedar. 2010.

"Epiphytism of Gracilaria cliftonii (Withell, Millar \&amp; Kraft) from Western Australia." Journal of Applied Phycology 22(3):371-79.

Neksidin, Utama. K. Pangerang, dan Emiyarti. 2013. "Studi Kualitas Air untuk Budidaya Rumput Laut (Kappaphycus alvarezii) di Perairan Teluk KolonoKabupaten Konawe Selatan." Jurnal Mina Laut Indonesia 3(12):147-55.

Onuoha, FC. 2008. "Environmental Degradation, Livelihood and Conflicts: A Focus on the Implications of the Diminishing Water Resources of Lake Chad for North-Eastern Nigeria." African Journal on Conflict Resolution 8(2):35-61.

Parenrengi, Andi, Rachmansyah, dan E. Suryati. 2010. Budi daya rumput laut penghasil karaginan (Karaginofit). Maros (ID): Balai Riset Perikanan Budidaya Air Payau.
Rangkuti, Freddy. 2015. Analisis SWOT Tenik Membelah Kasus Bisnis. Jakarta (ID): Gramedia Pustaka Utama.

Salusu, J. 2015. Pengambilan Keputusan Strategik untuk Organisasi Publik dan Organisasi non Profit. Jakarta (ID): Gramedia Widiasarana Indonesia (Grasindo). Stake, Robert E. 2009. Handbook of Qualitative Research. Yogyakarta (ID): Pustaka Pelajar.

Titi, Vangile dan Naresh C. Singh. 2002. Adaptive Strategies of the Poor in Arid and Semi-arid Lands: in Search of Sustainable Livelihoods. Wibianto, Setyo Angger. 2016. "Pengaruh Angin Terhadap Pembentukan Arah dan Kecepatan Arus Permukaan Di Wilayah Utara dan Selatan Jawa Timur [Skripsi]." Universitas Brawijaya. 